\title{
Pliocene freshwater pollen-bearing deposits in the Mizerna-Nowa borehole, West Carpathians, Poland
}

\author{
Krzysztof BIRKENMAJER ${ }^{1}$ and Elżbieta WOROBIEC $C^{2, *}$ \\ 1 Institute of Geological Sciences, Cracow Research Centre, Polish Academy of Sciences, Senacka 1, 31-002 Kraków, Poland \\ 2 W. Szafer Institute of Botany, Polish Academy of Sciences, Lubicz 46, 31-512 Kraków, Poland
}

Birkenmajer K. and Worobiec E. (2013) Pliocene freshwater pollen-bearing deposits in the Mizerna-Nowa borehole, West Carpathians, Poland. Geological Quarterly, 57 (1): 73-88, doi: 10.7306/gq.1075

This paper describes sedimentology and palynology of freshwater plant-bearing late Cenozoic (Pliocene sensu lato) deposits drilled at Mizerna, the eastern part of the Nowy Targ Intramontane Depression, West Carpathians, southern Poland. Our data were obtained from a newly-analysed $39 \mathrm{~m}$ thick succession from the Mizerna-Nowa borehole, containing spores, pollen and freshwater organic-walled algal micro-remains. They shed light on the palaeoenvironmental conditions of the Nowy Targ Intramontane Depression, where the Mizerna palaeolake once formed.

Key words: West Carpathians, Mizerna palaeolake, Pliocene, deposits, palaeoenvironment, palynology.

\section{INTRODUCTION}

This paper discusses the geology, sedimentology, palaeobotany, palaeoenvironments and stratigraphy of the freshwater late Cenozoic strata drilled in the Mizerna-Nowa borehole in the eastern part of the Nowy Targ Intramontane Depression, West Carpathians, southern Poland. The borehole, which was ca. 39 m deep, was drilled in June 1979 for scientific purposes. Sediment and palynological samples from this borehole are housed in the Museum of the W. Szafer Institute of Botany, Polish Academy of Sciences.

The Mizerna freshwater deposits, which are rich in well-preserved plant remains, have been known for over sixty years from the eastern termination of the Nowy Targ Intramontane Depression, at the entrance to the Pieniny Mountains (Czorsztyn Range) - see Figure 1. They are listed among the most important late Cenozoic palaeobotanical sites in central Europe. According to Szafer (1949, 1952, 1954), their macrofloral remains document the development, succession and changes of vegetation cover in the West Carpathians during the Pliocene and Early Pleistocene.

Oszast (in Szafer, 1954; Szafer and Oszast, 1964; Oszast, 1973) made the first palynological studies of the Mizerna freshwater deposits. In one borehole section, site "A" (see Fig. 2), she recognized an upwards decrease in a warm-temperate element, the "Tertiary trees", along with a simultaneous increase in herbaceous plant pollen. Seven successive floral assemblages, based on both macrofloral remains and pollen associations, were identified by Szafer and Oszast (1964), and their

\footnotetext{
* Corresponding author: e.worobiec@botany.pl
}

Received: April 30, 2012; accepted: October 8, 2012; first published online: February 26, 2013 character became a basis for constraining the Late Pliocene/Pleistocene boundary, as well as Early Pleistocene palaeoclimatic epochs, in the Mizerna succession.

A re-evaluation of the palaeoclimatic and stratigraphical significance of the macroflora, along with a reassessment of the palaeoenvironmental and sedimentary conditions during the formation of the Mizerna freshwater deposits, has recently been initiated by Zastawniak-Birkenmajer and Birkenmajer (2012). They also reopened the question of the Pliocene/Pleistocene boundary and the presence/absence of Early Pleistocene deposits at Mizerna. These topics are discussed here based on spore-pollen analysis prepared by E. Worobiec and sedimentological analysis of the borehole log by K. Birkenmajer.

\section{GEOLOGICAL SETTING}

During the Late Neogene, weathered material from Paleogene flysch strata - the sandstones and shales of the Magura Nappe which constitute the Gorce Mountain Range and its southern foothills, was redeposited by rainfall, slope creep and slumps and streams into a shallow lake that flooded the eastern part of the Nowy Targ Intramontane Depression. Two stages of infilling of this lake are inferred: (1) Miocene (?Middle Miocene), which was disturbed by the transverse faulting of the Styrian Phase, and (2) Pliocene.

1. The older stage is represented by thin plant-bearing freshwater deposits formerly exposed at Huba (Fig. 1: Huba 1cf. Birkenmajer et al., 2010). In 1949 they were penetrated by a shallow borehole down to their Paleogene flysch base, found at $7.5 \mathrm{~m}$ below the surface. Originally, these deposits were attributed to the Pliocene (Szafer, 1949, 1954) and later to the Miocene ("Badenian" - Oszast, 1973). Presently, the site is 


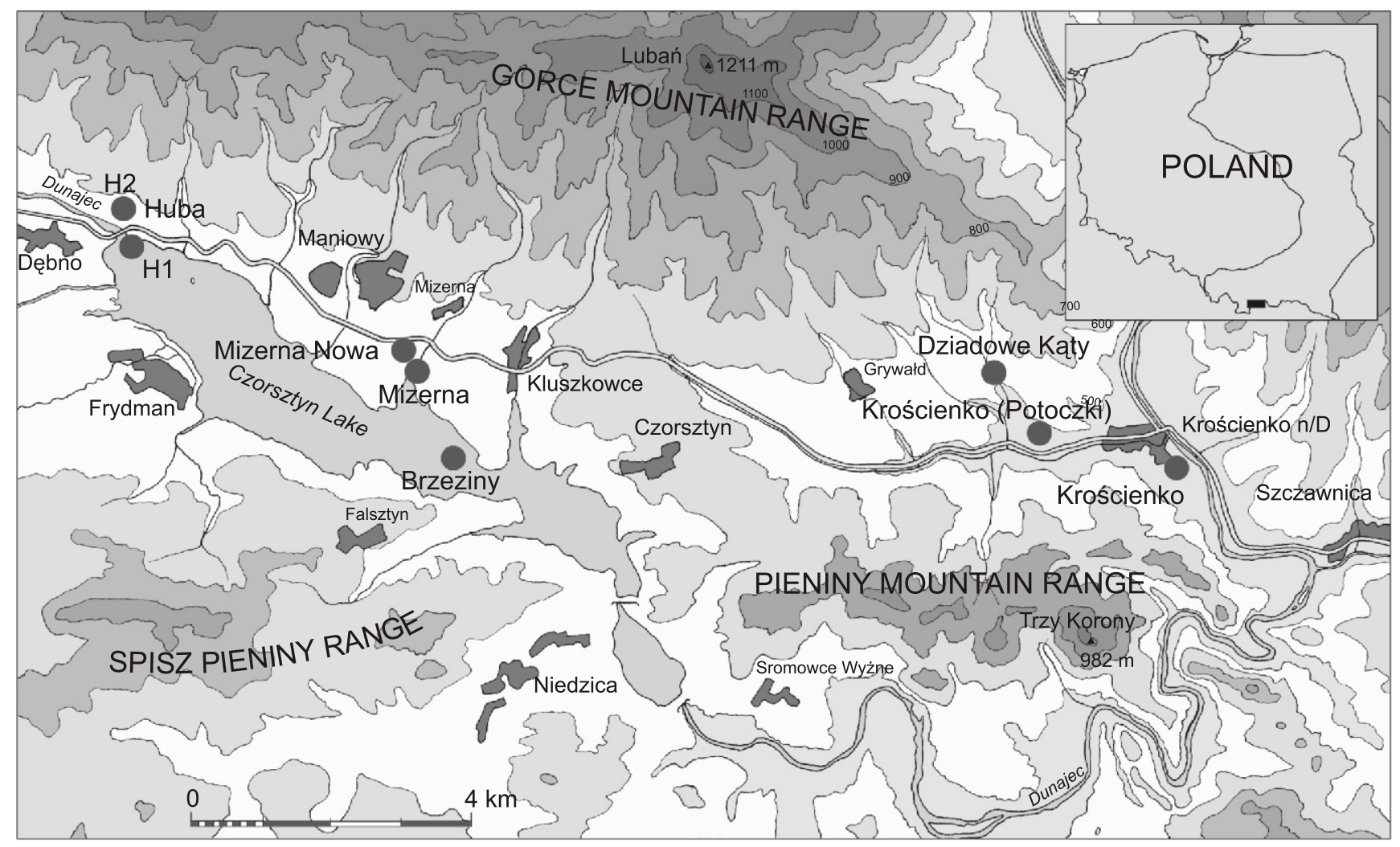

Fig. 1. Location of the Miocene, Pliocene and Pleistocene plant-bearing sites in the eastern part of the Nowy Targ Intramontane Depression and the Pieniny Mountains, West Carpathians, southern Poland (inserted map)

H 1 - Huba 1, Miocene; H 2 - Huba 2, Mindel/Riss Interglacial (= Mazovian Interglacial); Mizerna, Mizerna-Nowa - Pliocene; Brzeziny - Brørup Interstadial; Krościenko (Potoczki) - Pliocene; Dziadowe Katy and Krościenko - Late Pleistocene

drowned by the waters of the artificial Czorsztyn Lake (see Birkenmajer, 2010).

2. The younger stage is represented by freshwater plant-bearing deposits (Pliocene and Early Pleistocene after Szafer, 1954; Szafer and Oszast, 1964; Oszast, 1973): mainly sandy clays and sands, often with unworked fragments of flysch sandstone and shale, rich in well-preserved macroscopic plant remains. They were once exposed and drilled at Mizerna near Czorsztyn (Figs. 1-4). The main exposures, now under the water of the artificial Czorsztyn Lake, lay along the Mizerka and Koprocz streams - both left tributaries of the Dunajec River. The freshwater deposits fill a narrow buried valley about $600 \mathrm{~m}$ long (Fig. 2) eroded in the strongly folded Paleogene flysch beds of the Magura Nappe - the southernmost tectonic unit of the Outer Carpathians (see Birkenmajer, 1954, 1958, 1961, 1963, 1979).

In a deeper part of the Mizerna succession, there occurs a $1.7 \mathrm{~m}$ thick intercalation of loose sandy gravels consisting of rounded to well-rounded pebbles of Lower Triassic quartzite, Carboniferous granite and pegmatite derived from the Tatra Mountains. This is the first sign that rivers, which were dissecting the Tatra Massif and its Paleogene cover, finally reached down to the core of the massif (Birkenmajer, 1954, 2009).

Mizerna-type plant-bearing freshwater deposits have also been encountered in a borehole about $100 \mathrm{~m}$ below the Dunajec River bed in the Frydman Graben, in the easternmost part of the Nowy Targ Intramontane Depression (Niedzielski, 1971). The capping deposits are mainly represented by the Tatra Mts.-derived glaciofluvial gravel, correlatable with the
Mindel and Riss glaciations of the Tatra Mts., and divided by an interglacial-type freshwater sequence, correlatable with the Mindel/Riss (Mazovian Interglacial) lacustrine deposits at Huba, west of Mizerna (cf. Birkenmajer, 1979; Birkenmajer et al., 2010). The downfaulting which produced the Frydman Graben most probably happened during the Riss/Würm Interglacial.

The northern boundary fault which divides the Pieniny Klippen Belt from the Magura Nappe contact has intermittently been active throughout the Quaternary: during the Mindel/Riss Interglacial, at Szaflary Quarry (Birkenmajer and Stuchlik, 1975; Birkenmajer, 1976); during the Riss/Würm Interglacial, or later, at Huba 2 (Birkenmajer et al., 2010); even now, weak earthquakes affect the tectonic zone of the Pieniny Klippen Belt and its vicinity.

The Mizerna-Nowa borehole studied is located on the left slope of the Koprocz Stream (Fig. 4). Its stratigraphic description is given in Appendix $1^{*}$.

\section{STRATIGRAPHIC SUBDIVISION AND THE SEDIMENTARY PALAEOENVIRONMENT}

The Mizerna-Nowa borehole succession may be subdivided into four parts (A-D), which differ in the proportion of lacustrine bottom clay ( $\mathrm{Lc}$ ) to river sand and gravel $(\mathrm{Fs}+\mathrm{g}$ ) deposits, and in the presence or absence of subaqueous slump struc- 


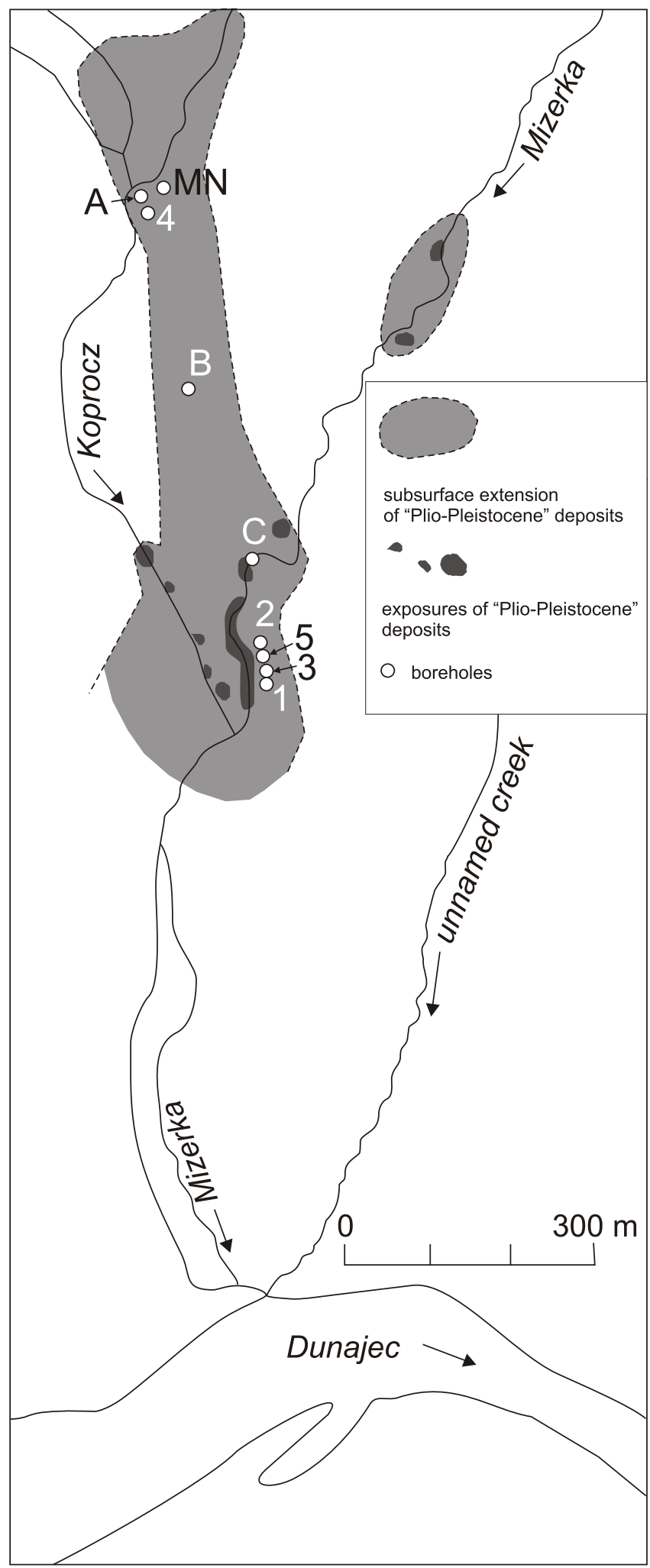

Fig. 2. Mizerna site - buried river valley filled with fluvial and lacustrine Pliocene and "Plio-Pleistocene" deposits

Boreholes (A, B) and natural exposures (1-5, C) as in Szafer (1954) and Birkenmajer (1954, 1958, 1961); MN - Mizera-Nowa borehole tures (Fig. 5). This subdivision reflects the sedimentary/palaeoenvironmental history of the freshwater Mizerna palaeolake which, during the late Cenozoic, occupied the easternmost part of the Nowy Targ Intramontane Depression, and was dammed to the east by a rocky threshold of the Zielone Skałki-Czorsztyn Castle klippes.

The history of the Mizerna palaeolake was certainly interconnected with the stages of formation of the Dunajec River Gap through the Pieniny Mountain Range. This will be discussed separately. Here, we note only some features having a bearing on the history of the palaeolake:

- the Mizerna palaeolake probably occupied an area of about $8 \times 2 \mathrm{~km}$, between Dębno-Huba in the west, and the Spisz Pieniny-Gorce Ranges in the east, being comparable in location and size to the present artificial Czorsztyn Lake (see Fig. 1);

- the buried river valley of Mizerna, a tributary of the Dunajec River, represented the northern bay of the palaeolake;

- the lake was probably very shallow and intermittently filled by sand and gravel brought from the southern slopes of the Gorce Mountain Range by rivers, slope creep and landslides;

- the typical lake deposits are represented by bottom clay with fragmented plant remains;

- channelling of the lake sediment by water currents, either underwater or in subaerial conditions, was difficult to demonstrate in our borehole. As suggested by some exposures (now unavailable because of drowning by the artificial lake), the sand often filled erosional channels;

- it is likely that earthquakes played an important role in the formation of the lower part of the succession, triggering subaqueous slumps of unconsolidated deposits.

\section{BEDROCK}

The bedrock of the Mizerna deposits is represented by the oldest lithostratigraphic units of the Magura Nappe (Birkenmajer, 1963): the Szczawnica Formation (Paleocene-Lower Eocene) and the Zarzecze Formation (previously Sub-Magura Beds, Eocene - Birkenmajer, 1963; for formalization of the lithostratigraphic units see Birkenmajer and Oszczypko, 1988, 1989). During the Pliocene, the easternmost part of the Nowy Targ Intramontane Depression was already deeply incised by the Dunajec River and its tributaries: down to ca. $505 \mathrm{~m}$ above sea level (a.s.l.) in the major valley, and down to $512 \mathrm{~m}$ a.s.l. in the Mizerka-Koprocz streams (Fig. 4). The regional fluvial pattern had therefore been stabilized before inundation by the Mizerna palaeolake.

The occurrence of a $2 \mathrm{~m}$ thick fossil soil (regolith), at about $512 \mathrm{~m}$ a.s.I., below the Mizerna deposits, indicates a quiet period of weathering which preceded inundation by the palaeolake waters.

\section{(A) FLUVIAL STAGE}

The basal part of the succession, which is $7 \mathrm{~m}$ thick (beds 1-9-see Fig. 5, Appendix 1), displays fluvial features: gravel beds $(\mathrm{Fg})$ consisting of angular fragments of local flysch strata alternating with sand beds (sand bars - Fs). With the exception of the lowest bed (bed 1: 35.7-36.0 m), which contains flat 


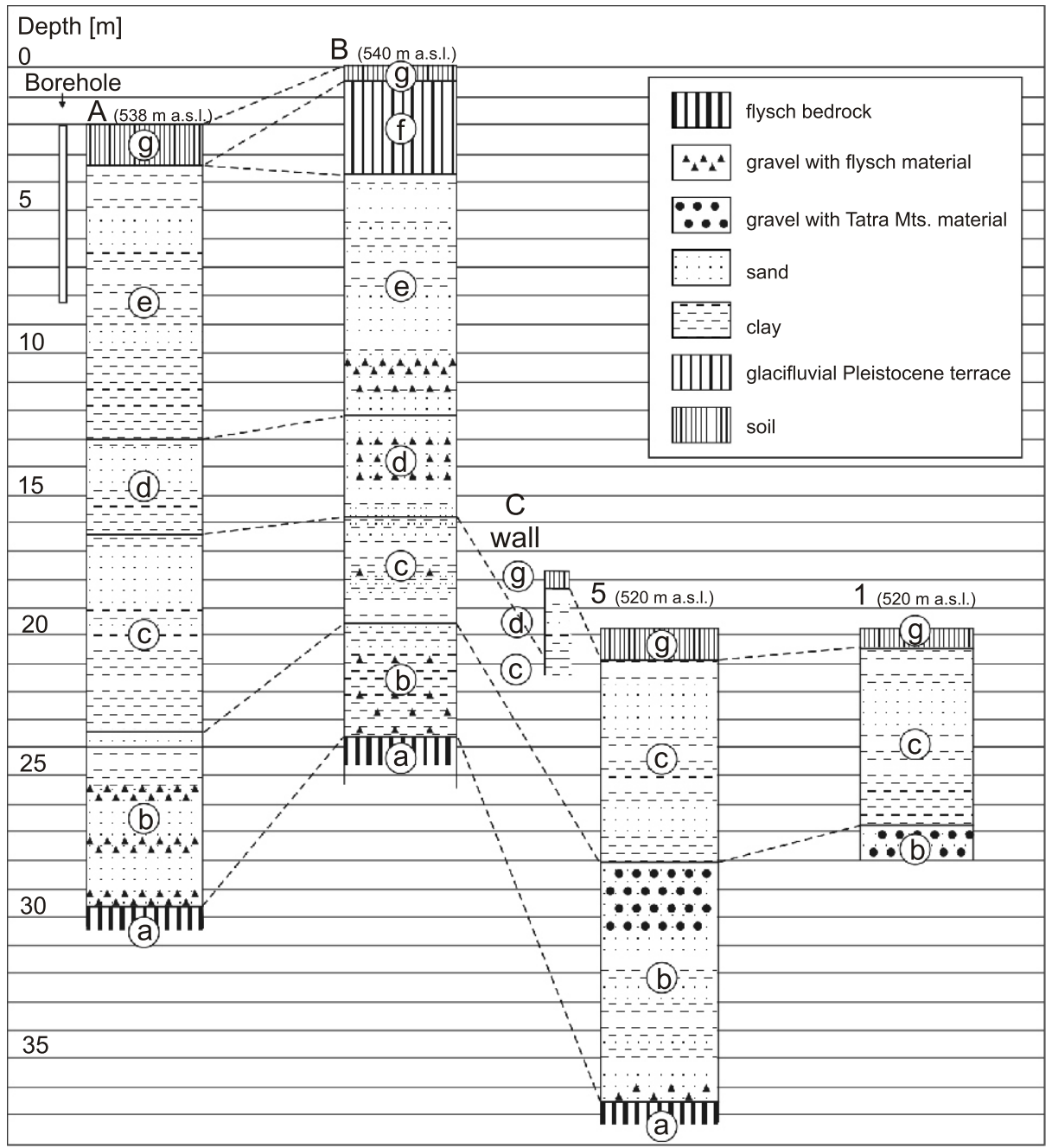

Fig. 3. Mizerna site - geological structure of the fluvial to lacustrine deposits (after Birkenmajer, in Szafer, 1954, slightly modified)

a - Eocene; b-e - after Szafer (1954): b - Middle Pliocene (pre-Günz), c - Upper Pliocene, d - Günz Glaciation, e - Günz-Mindel Interglacial (Tegelen); f, g - Pleistocene-Holocene; for location of boreholes and natural exposures see Figure 2

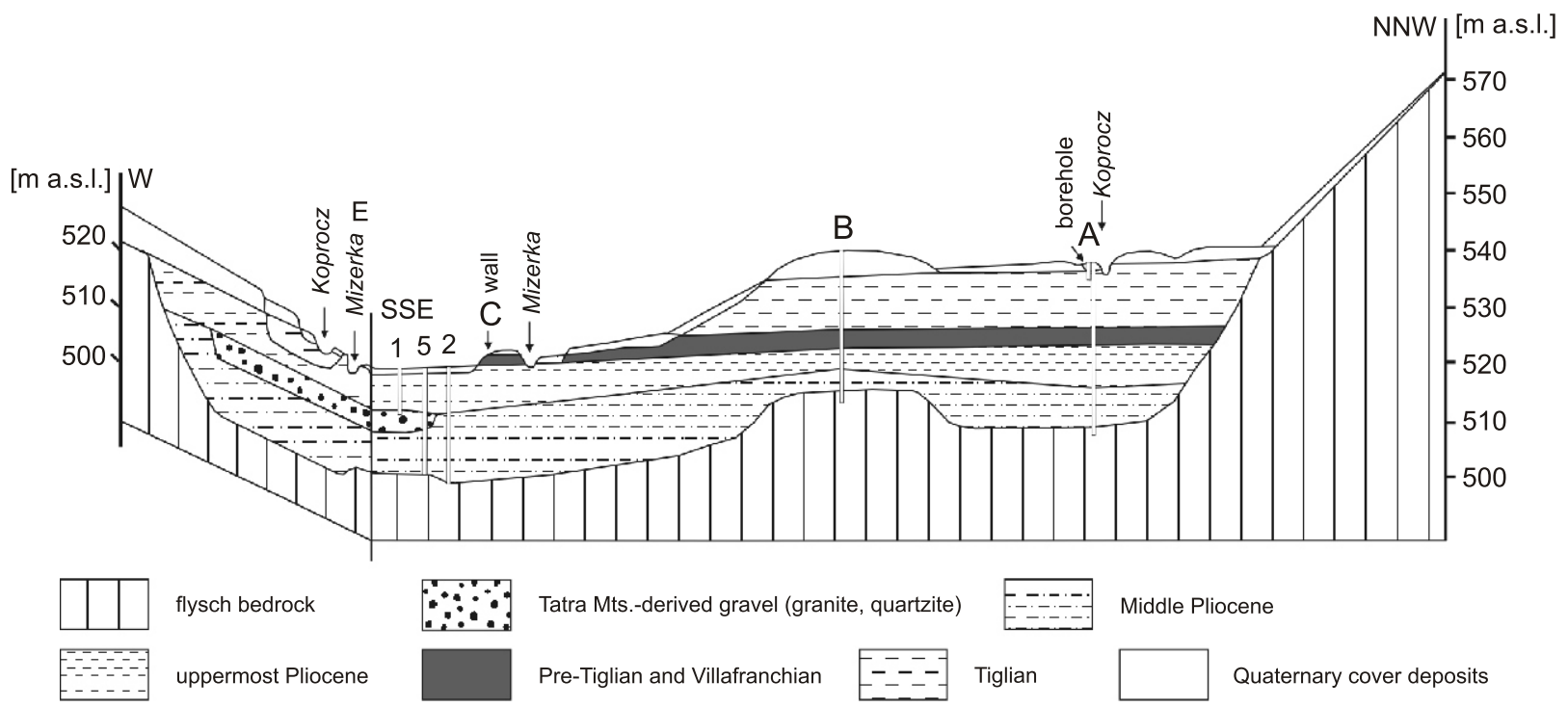

Fig. 4. Mizerna site - geological cross-section/block-diagram of fluvial-lacustrine "Plio-Pleistocene" deposits (Birkenmajer, 1961, 1979; ages of "Plio-Pleistocene" deposits after Szafer, 1954)

For location of boreholes and natural exposures see Figure 2 


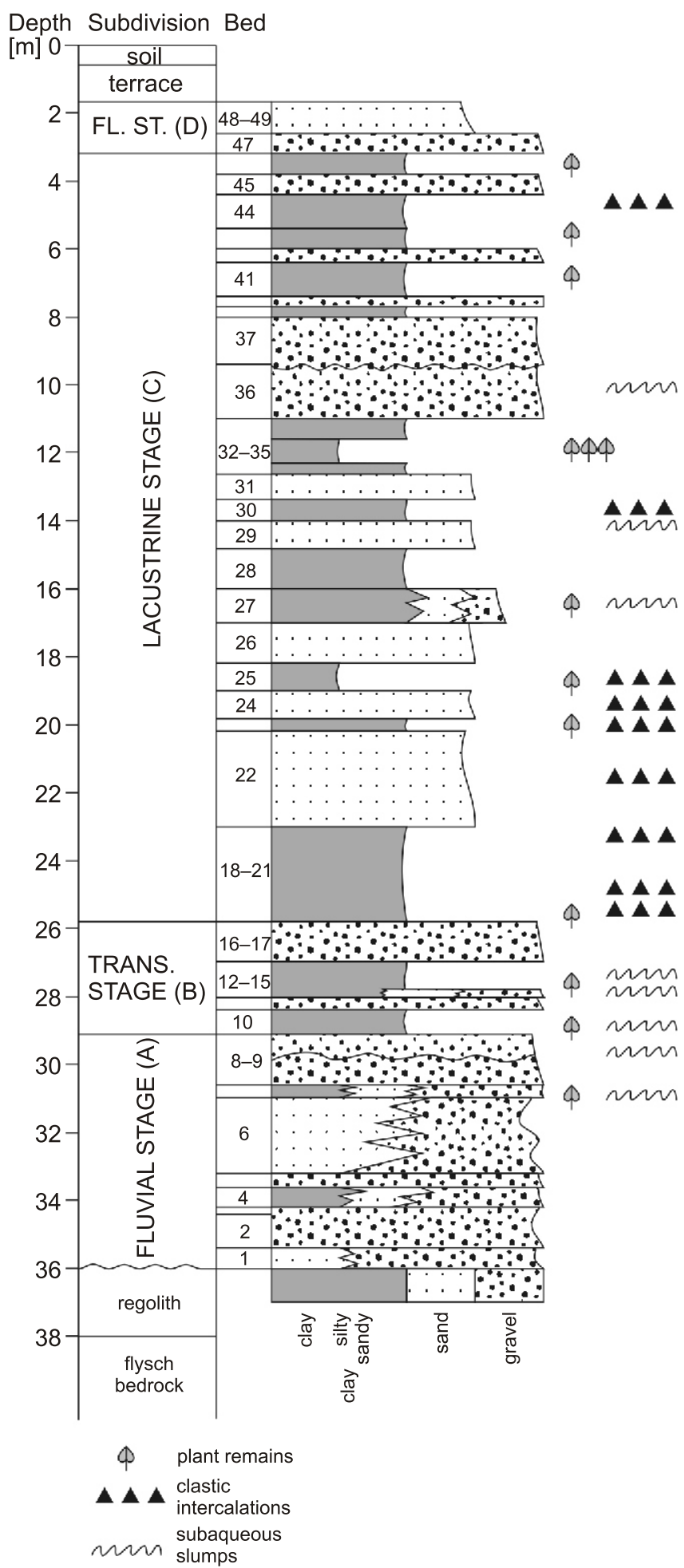

Fig. 5. Sedimentary log and lithostratigraphic subdivision (A-D) of freshwater deposits in the Mizerna-Nowa borehole

\section{FL. ST. - fluvial stage; TRANS. STAGE - transitional stage}

sandstone pebbles typical of fluvial gravel derived in the Podhale area from Paleogene flysch strata, the remaining gravel beds consist of unabraded (predominantly angular) small flysch sandstone and shale fragments. Both the gravel and sand beds are often impure - the gravel is mixed with clay $(\mathrm{Fg}+\mathrm{C})$, with sand $(\mathrm{Fg}+\mathrm{s})$, or with both $(\mathrm{Fg}+\mathrm{C}+\mathrm{s})$. They were de- rived from the river-reworked cover of surrounding hills which, triggered by earthquakes, slid down the palaeovalley. The palaeoriver deposit shows numerous traces of subaqueous slumping (S), particularly in the chaotic arrangement of lignite fragments $(\mathrm{Fg}+\mathrm{p} / \mathrm{S})$. However, neither plant stems in growth position, nor roots/rootlets (rhizoliths) have been found.

As a whole, the 7-m succession of basal fluvial deposits represents a small delta laid down in the buried river valley at its outlet to the palaeolake. Evidence for this is visible in the top part of the fluvial succession (beds 12, 13: 28.0-27.1 m), where fluvial deposits alternate with lake clay $(\mathrm{Lc} / \mathrm{Fg}+\mathrm{p} ; \mathrm{Lc}+\mathrm{s}+\mathrm{g})$.

\section{(B) TRANSITIONAL STAGE}

There is a clear transition from fluvial deposits $(\mathrm{Fg}, \mathrm{s})$ to lacustrine deposits (Lc). This reflects inundation of the area of the eastern Nowy Targ Intramontane Depression by the Mizerna palaeolake. In the transition zone (beds 10-17: 28.55-25.85 m) deposits of both environments are interbedded.

\section{(C) LACUSTRINE STAGE}

This stage is characterized by bottom clay deposits (LC) laid down in a shallow lake often disturbed by bottom currents that deposited sand bars ( $L C+p)$ and even gravel bars $(F g)$. This is the thickest part of the Mizerna succession (beds 18-46: 25.85-3.9 m) - 21.95 $m$ thick. The predominant part is formed by lake-bottom clay (Lc), usually with a considerable admixture of fragmented plant remains $(L c+p)$. Intercalations of gravel $(\mathrm{Fg})$ and sand $(\mathrm{Fs}$; $\mathrm{LC}+\mathrm{S}$; $\mathrm{LC}+\mathrm{S}+\mathrm{g})$ are more frequent in lower part of the unit, some evidently filling erosional channels (Fsch). Subaqueous slumping has occasionally been recognized.

\section{(D) FLUVIAL STAGE}

This stage terminates the sedimentary history of the Mizerna freshwater basin. The lake-bottom clays (Lc) were replaced by fluvial gravel and sand bar $(\mathrm{Fg}+\mathrm{s}$; Fs), $1.6 \mathrm{~m}$ thick (beds 47-49: 3.2-1.6 m) and devoid of fossil plant remains. It is probable that, at that time, the Dunajec River forced a natural rocky threshold that dammed the Mizerna palaeolake from the east, causing its complete draining. Whether this had happened already during the Pliocene, or during the long Eopleistocene epoch that divided the Pliocene from the first Pleistocene glaciation (Mindel Glaciation) of the Tatra Mountains (Birkenmajer, 2009), is presently a matter of guesswork.

\section{PALYNOLOGICAL STUDY}

\section{MATERIAL AND METHODS}

The material for palynological analysis was sampled from the Mizerna-Nowa borehole core. In most cases the samples were taken every 10 to $20 \mathrm{~cm}$. The sampling was at larger intervals in sand and gravel beds. The samples were processed according to a modified Erdtman's acetolysis method (Moore et al., 1991) using hydrofluoric acid to remove mineral matter. Additionally, the material was sieved at $5 \mu \mathrm{m}$ on a nylon mesh. The microscope slides were made using glycerine jelly or glycerine as a mounting medium. A total of 160 samples have been studied and at least two microscope slides from each sample were examined.

The sporomorph taxa identified have been classified (see Appendix 2) mainly with reference to an Atlas of pollen and 


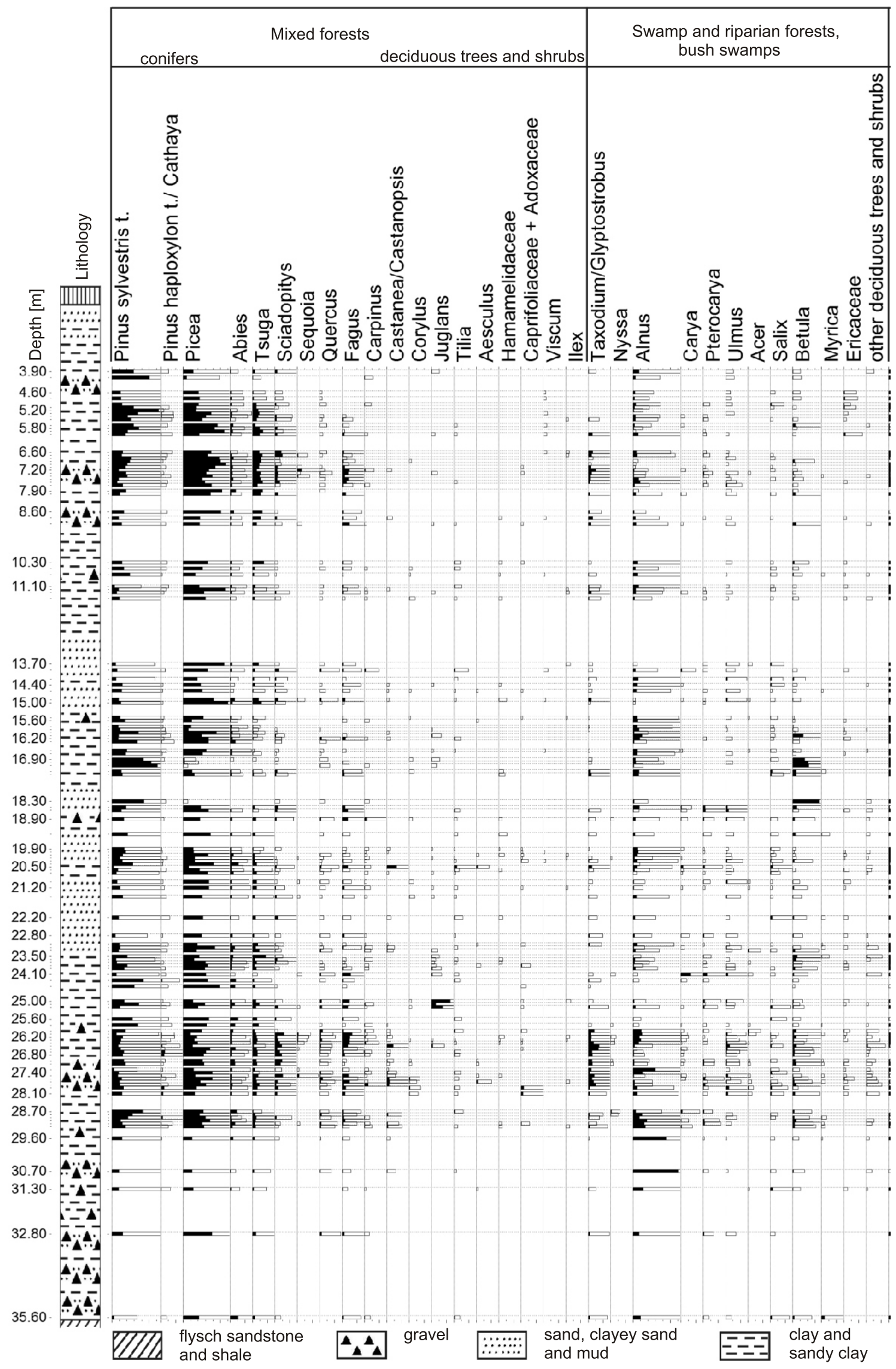

Fig. 6. Percentage diagram of selected 


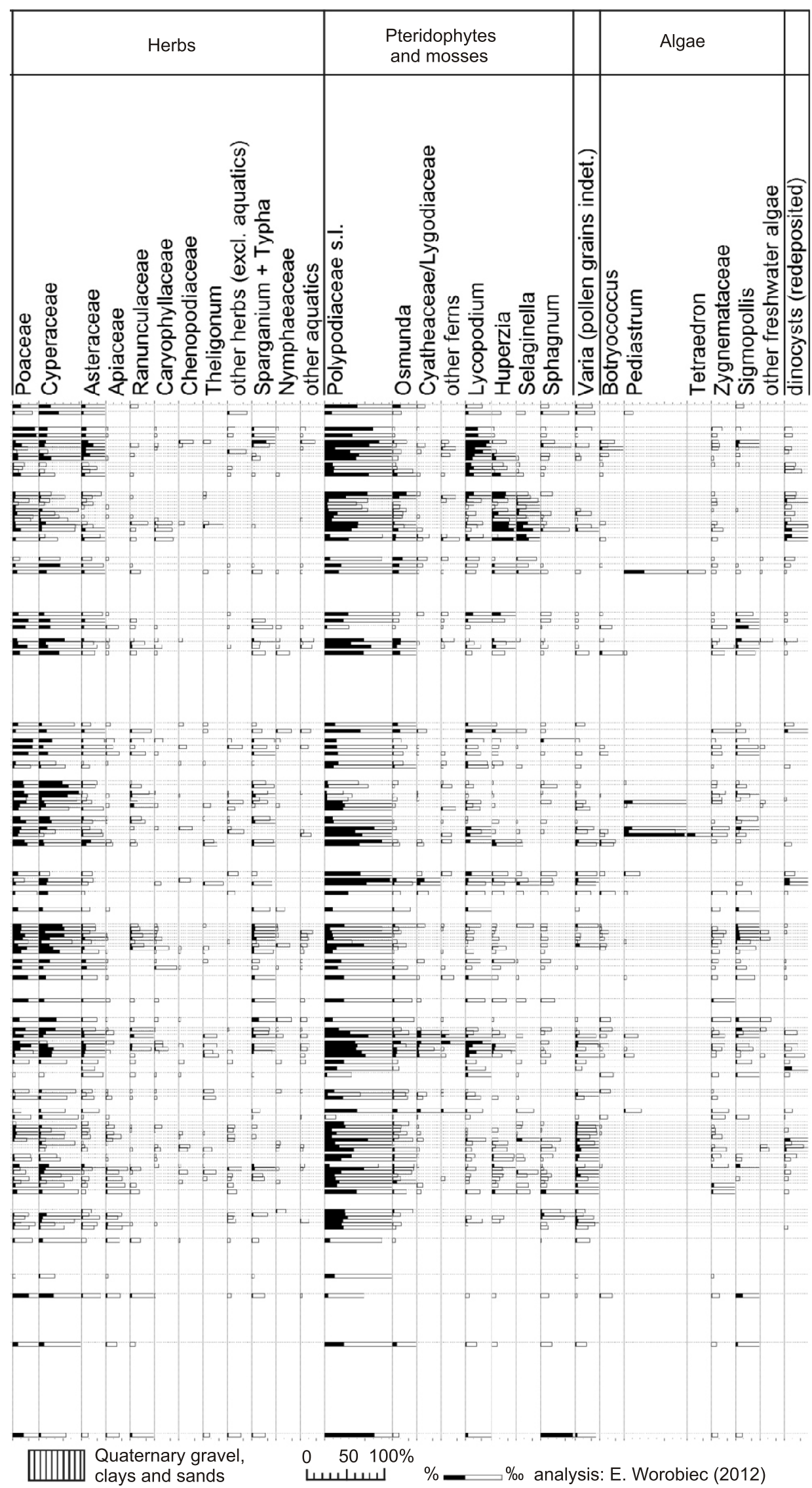



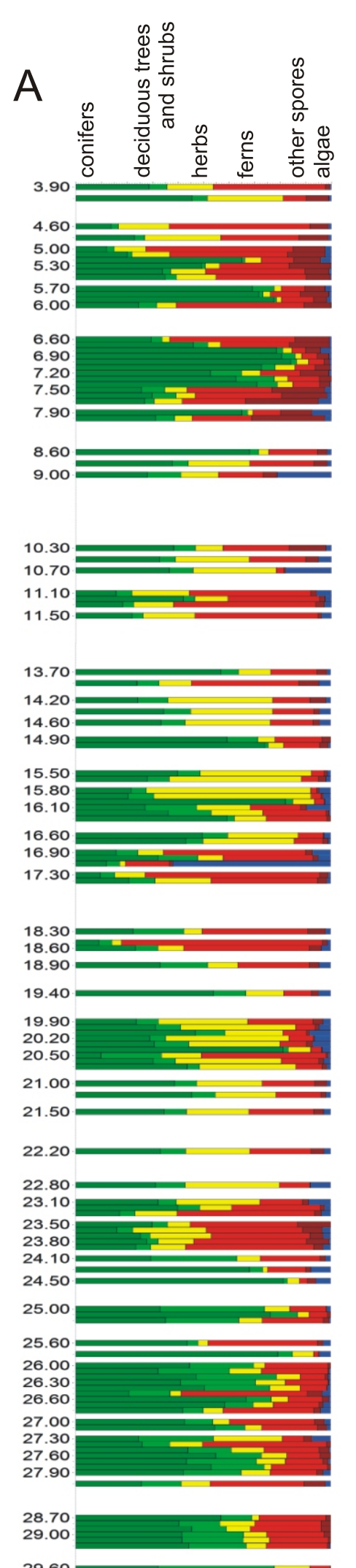

$29.60=$

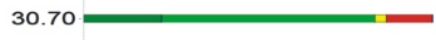

$31.30=$

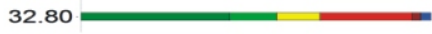

$35.60=-\quad-\quad-\quad-\quad-50 \%$
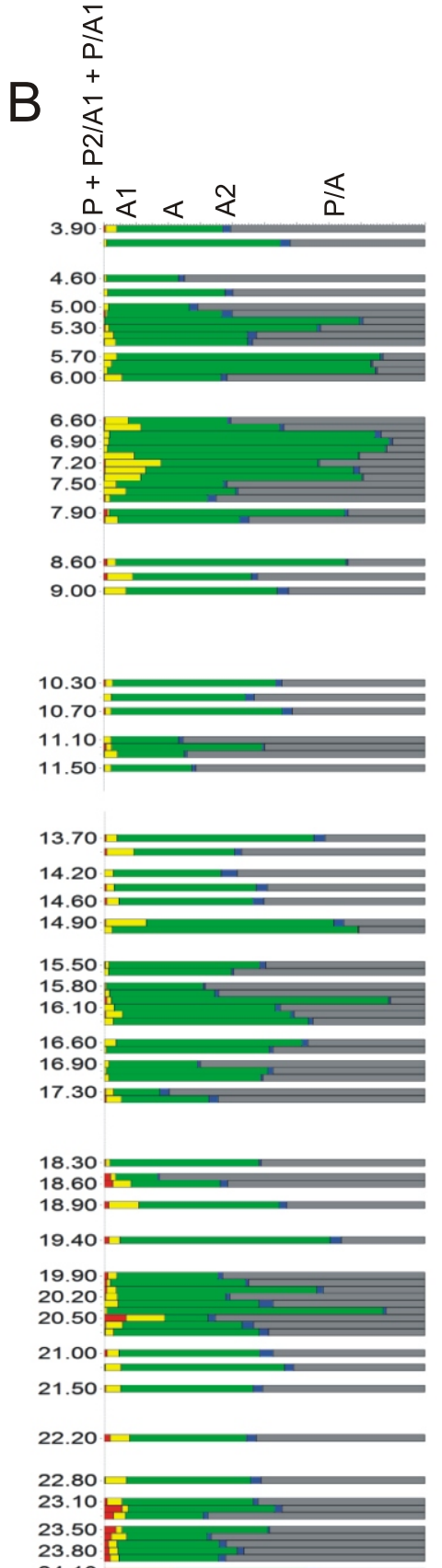

23.10
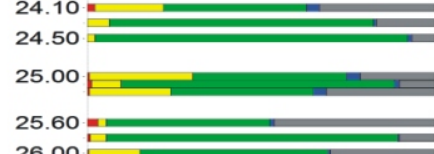

26.00

26.30

26.60

27.00 D

27.30

$27.60 \geq$
$27.90 \geq$

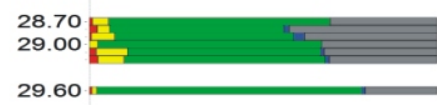

29.60
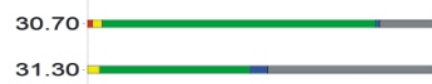

$32.80=$

$35.60=50 \%$ spores of the Polish Neogene (Stuchlik et al., 2001, 2002, 2009) and the checklist of selected pollen and spore taxa from the Neogene deposits proposed by Ziembińska-Tworzydło et al. (1994).

Data from the spore-pollen spectra have been used to construct a simplified pollen diagram presenting frequencies of pollen, spores, and algae (Fig. 6). The percentage shares of the pollen taxa presented in the diagram have been calculated from the total sum of pollen grains; the proportions of spores and algal micro-remains were computed separately in relation to the total sum using the POLPAL computer program (Nalepka and Walanus, 2003). Most taxa have their own columns. However, some columns present the sum of a few taxa (two or more genera, one family or a few families). In addition, two diagrams, showing the frequency of pollen grains of a particular group of plants, spores and algae (Fig. 7A) and palaeofloristical elements (Fig. 7B) have been constructed, also using the POLPAL program. Microphotographs of selected taxa (Figs. 8-10) were taken using a NIKON Eclipse microscope fitted with a Canon digital camera.

\section{RESULTS OF THE PALYNOLOGICAL STUDIES}

Sporomorph assemblages suitable for detailed studies were found in 125 samples. In each of these samples an average of 200-300 pollen grains and all the accompanying spores and algal micro-remains were counted. For several low frequency samples, the basic sum was reduced to about 100-150 grains. The state of preservation of the palynomorphs varies from very well-preserved specimens to corroded ones with a highly damaged structure. Thirty-five samples from various intervals were barren or only yielded sparse palynomorphs. Most barren samples were taken from fluvial deposits, whereas the richest and best preserved sporomorphs were in samples taken from finegrained sediment.

Pollen spectra from the samples that were studied in detail are more or less taxonomically diverse: in most samples, 20-40 (sporadically up to 50) taxa of pollen, spores and algae occur. A total of 145 taxa of sporomorphs, including 26 taxa of spores, 28 taxa of gymnosperm pollen and 91 taxa of angiosperm pollen have been identified (their listing, botanical affinity and palaeofloristical element are given in Appen-

Fig. 7A - frequency of pollen grains of particular groups of plants, spores and algae in samples studied from Mizerna-Nowa; B - ratios of palaeofloristical elements in samples studied from Mizerna-Nowa

Palaeofloristical elements: A - arctotertiary (A1 warm-temperate, A2 - cool-temperate); P - palaeotropical (P1 - tropical, P2 - subtropical); P/A - cosmopolitan 

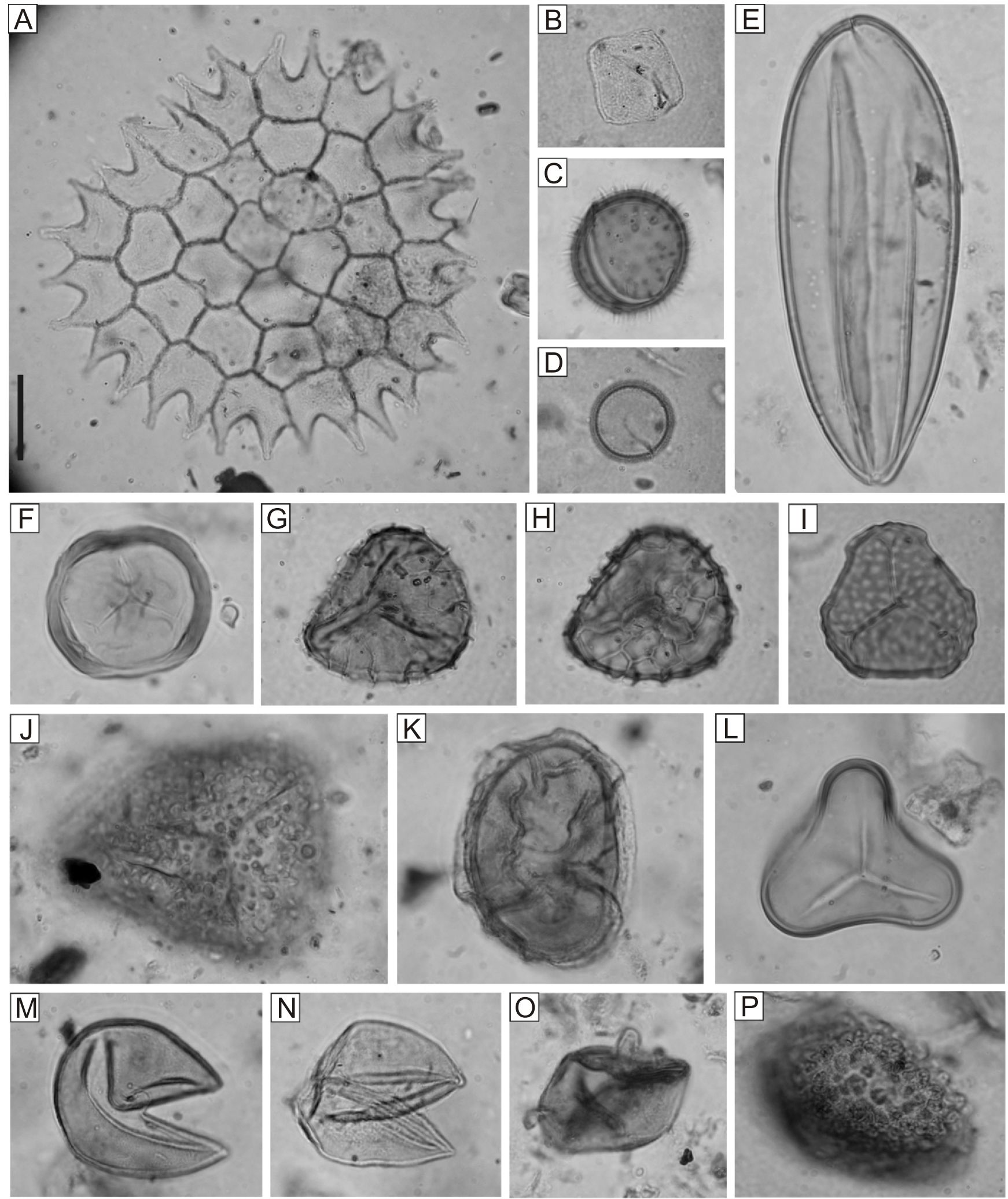

Fig. 8. Freshwater algae, spores and pollen grains from the Mizerna-Nowa borehole

A - Pediastrum boryanum (Turp.) Menegh., depth $17.1 \mathrm{~m}$; B - Tetraedron minimum (A. Braun) Hansgirg, depth $17.1 \mathrm{~m}$; C - Sigmopollis pseudosetarius (Weyland et Pflug) Krutzsch et Pacltová, depth 15.9 m; D - Sigmopollis laevigatoides Krutzsch et Pacltová, depth 15.8 m; E - Ovoidites grandis (Pocock) Zippi, depth 26.3 m; F - Distancoraesporis sp., depth 20.2 m; G, H - Retitriletes sp., depth 10.7 m; I Selagosporis selagoides Krutzsch, depth 7.4 m; J - Baculatisporites major (Raatz) Krutzsch, depth 26.1 m; K - Perinomonoletes sp., depth $28.8 \mathrm{~m} ; \mathbf{L}$ - Leiotriletes neddenioides Krutzsch, depth 25.6 m; M - Inaperturopollenites sp., depth 29.1; N - Inaperturopollenites dubius (Potonié et Venitz) Thomson et Pflug, depth $25.8 \mathrm{~m}$; O - Sequoiapollenites sp., depth $26.3 \mathrm{~m}$; P - Sciadopityspollenites serratus (Potonié et Venitz) Raatz, depth $7.4 \mathrm{~m}$; scale bar $-20 \mu \mathrm{m}$ 

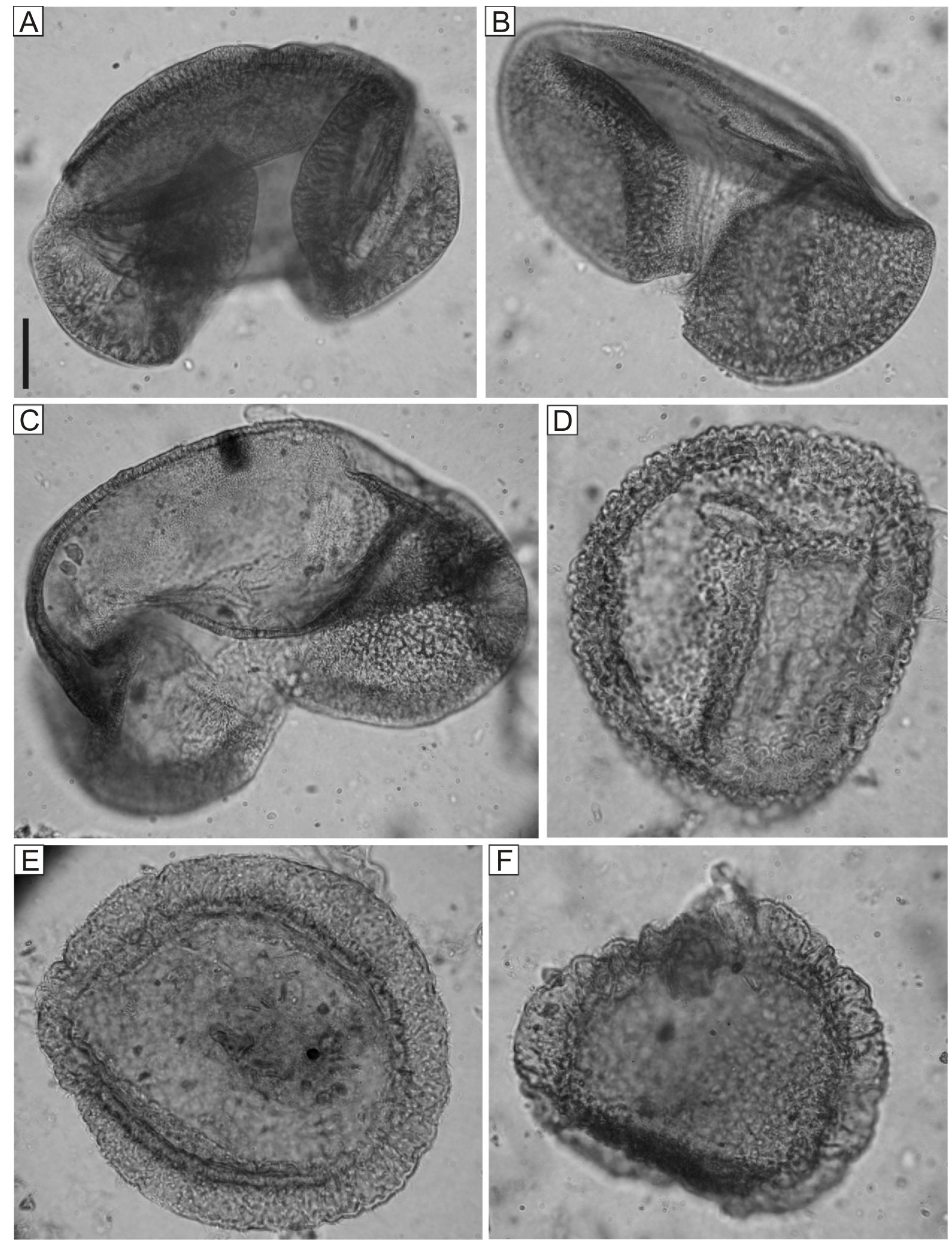

Fig. 9. Pollen grains from the Mizerna-Nowa borehole

A - Abiespollenites absolutus Thiergart, depth $25.8 \mathrm{~m}$; B - Piceapollis tobolicus (Panova) Krutzsch, depth 25.8 m; C - Piceapollis planoides Krutzsch ex Hochuli, depth 20.2 m; D - Zonalapollenites verrucatus Krutzsch ex Ziembińska-Tworzydło, depth 20.2 m; E - Zonalapollenites sp., depth 26.3 m; F - Zonalapollenites spinosus (Doktorowicz-Hrebnicka) Ziembińska-Tworzydło, depth 15.9 m; scale bar - 20 um 

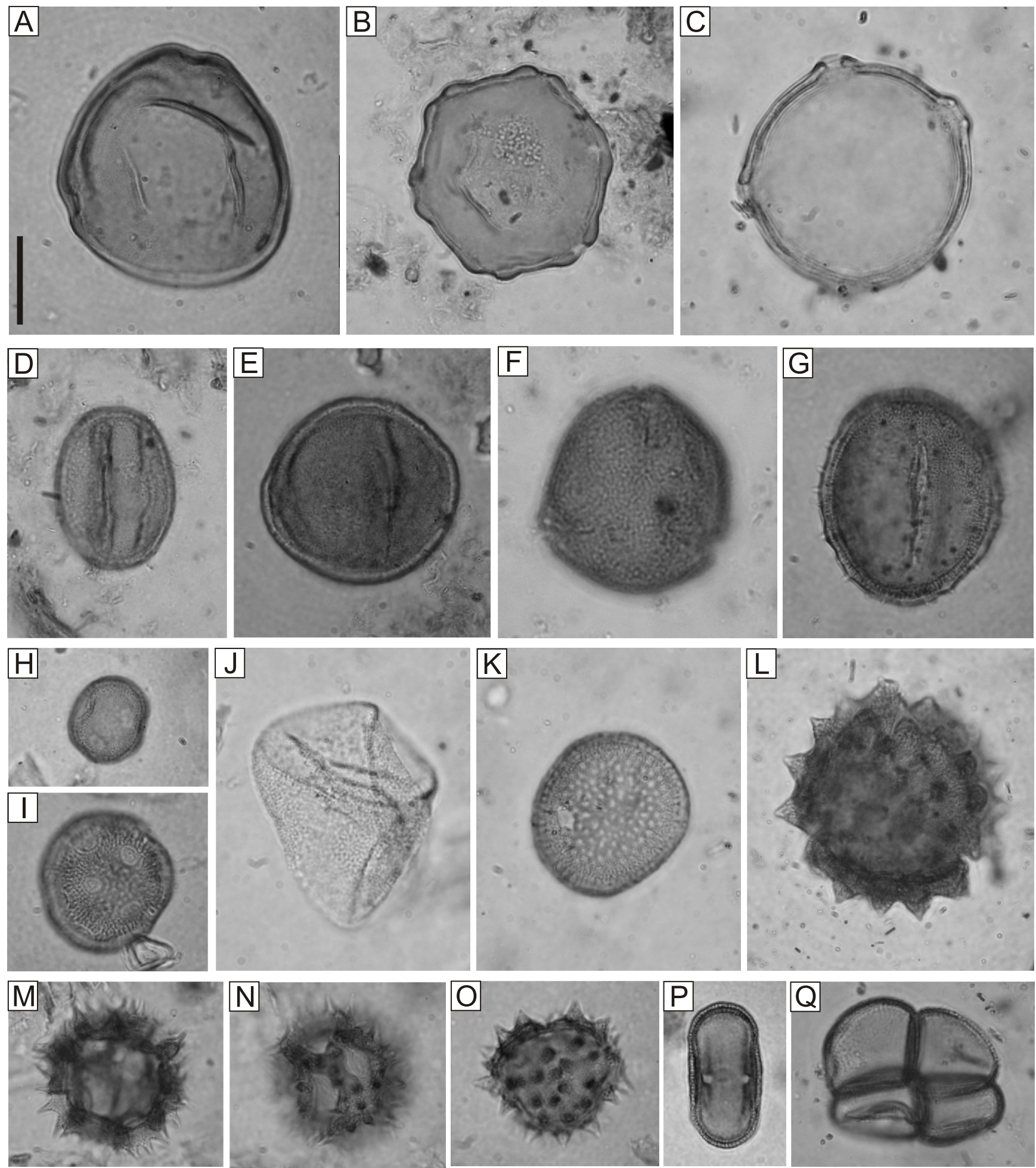

Fig. 10. Pollen grains from the Mizerna-Nowa borehole

A - Caryapollenites simplex (Potonié) Raatz, depth 7.4 m; B - Polyatriopollenites stellatus (Potonié) Pflug, depth 26.4 m; C - Carpinipites carpinoides (Pflug) Nagy, depth $17.1 \mathrm{~m}$; D - Quercopollenites poratus Kohlman-Adamska et Ziembińska-Tworzydło, depth 26.3 m; E Faguspollenites sp., depth 26.4 m; F - Faguspollenites sp., depth 7.0 m; G - Tricolporopollenites viscoides Stuchlik, depth 20.2 m; H Thalictrumpollis thalictroides Stuchlik, depth $20.2 \mathrm{~m}$; I - Caryophyllidites hidasensis Nagy, depth $7.4 \mathrm{~m}$; J - Cyperaceaepollis neogenicus Krutzsch, depth 20.4 m; K - Sparganiaceaepollenites neogenicus Krutzsch, depth 15.9 m; L - Tubulifloridites macroechinatus Nagy, depth 10.7 m; M, N - Cichoreacidites gracilis (Nagy) Nagy, depth 7.4 m; O - Tubulifloridites granulosus (Trevisan) Nagy, depth 20.2 m; P Umbelliferoipollenites tenuis Nagy, depth 29.1 m; Q - Tetradomonoporites typhoides Krutzsch, depth 15.9 m; scale bar - $20 \mu \mathrm{m}$ 
dix 2). In addition, 24 taxa of freshwater algae have been identified (Appendix 3).

Bisaccate pollen related to conifers (Pinaceae) strongly prevails among the pollen grains. In most samples Picea (mainly Piceapollis tobolicus) and Pinus (mainly Pinuspollenites labdacus) strongly dominate. Additionally, frequent Tsuga, Sciadopitys (mainly Sciadopityspollenites serratus), Abies, and Cathaya pollen grains occur. Taxodium/Glyptostrobus pollen is encountered regularly, but in low frequencies. Sequoia pollen grains are found sporadically.

Deciduous trees are represented mainly by: Alnus, Betula, Fagus, Quercus (Quercopollenites), UImus, Salix, Pterocarya, Carya, and Juglans (Juglanspollenites). Pollen from Carpinus, Tilia, Acer, Aesculus, Corylus, Hamamelidaceae (Corylopsis and Tricolporopollenites indeterminatus), Myrica, and others, is encountered regularly. Castanea/Castanopsis (mainly Cupuliferoipollenites oviformis) and Nyssa (Nyssapollenites sp.) pollen mainly occurs in the lower section of the profile. Ericaceae are found regularly but in very low frequencies. Caprifoliaceae, Adoxaceae, Ilex (mainly llexpollenites margaritatus), Rosaceae, Viscum, and others, are encountered sporadically.

In the samples studied, herbs are represented by sedges, grasses, Asteraceae, Apiaceae, Ranunculaceae, Caryophyllaceae, Chenopodiaceae, Theligonum, and others. Aquatic and wetland plants are mainly represented by pollen from Sparganiaceae, Typha, Potamogeton, Alismataceae, Nymphaeaceae, Utricularia, and others.

Fern spores, mainly Polypodiaceae s.I., Osmunda (mainly Baculatisporites) and, in some samples, also spores from the morpho-genus Leiotriletes (?Lygodiaceae, ?Cyatheaceae), are very important components of the sporomorph assemblages. In addition, numerous Lycopodium (variable in form), Huperzia, and Selaginella (Echinatisporis longechinus) spores have been found. Sphagnum spores are only numerous in the lowermost sample, but in other samples they occur subordinately.

Freshwater algal taxa also occur relatively frequently, mainly Sigmopollis, Botryococcus and Zygnemataceae zygospores (Cycloovoidites, Diagonalites, Ovoidites, Stigmozygodites and Zygodites), as well as freshwater dinoflagellate cysts, and others. In some samples Pediastrum (mainly P. boryanum and $P$. integrum) as well as Tetraedron minimum occur.

In addition, single specimens of micro-fungi (sporocarps of Microthyriales and Tetraploa type) and fungal spores, as well as fragments of plant tissue (sclereids of Nymphaeaceae, dispersed stomata and cuticles) have been found. Several recycled dinocyst specimens were recorded in the samples investigated. They are probably recycled from Paleogene flysch rocks.

In the material studied the following palaeofloristical elements have been identified: palaeotropical $(P)$, including: tropical (P1) and subtropical (P2); and arctotertiary (A), including: warm-temperate (A1) and cool-temperate (A2), as well as cosmopolitan (P/A) elements. The composition of the pollen spectra shows an apparent dominance of arctotertiary (including warm-temperate and cool-temperate) and cosmopolitan palaeofloristical elements (Fig. 7B). Palaeotropical elements are represented by a few taxa only (mainly subtropical), all occurring as rare specimens (Leiotriletes neddenioides spores, and Corsinipollenites ludwigioides, Symplocoipollenites vestibulum, and Tricolporopollenites indeterminatus pollen grains). Some taxa (e.g., Rugulatisporites quintus spores, and Inaperturopollenites concedipites, I. verrupapilatus, AraliaceoipoIlenites sp., Cupuliferoipollenites oviformis, C. pusillus, Ilexpollenites iliacus, I. margaritatus, Magnoliaepollenites sp., Myricipites sp., Nyssapollenites sp., Spinulaepollis arceuthobioides, Tricolporopollenites exactus, $T$. fallax and T. liblarensis pollen grains) represent a palaeotropical/warm-temperate element.
In the samples studied, marked changes in the frequency and preservation of sporomorphs were undoubtedly related to the process of deposition. Nevertheless, changes in the composition of sporomorph assemblages (Figs. 6 and 7A), probably caused by both average temperatures and humidity, are also present. For example, apart from the permanent domination of conifers, in the lower section of the profile, pollen grains from deciduous trees and shrubs are more frequent and richer in taxa. This part is the richest in palaeotropical and warm-temperate elements (Fig. 7B), representing both deciduous trees and ferns. Later these were replaced by herbs, including Artemisia and Ambrosia. In the uppermost section, conifers (especially Picea and Tsuga) strongly dominate among the pollen taxa, whereas Lycopodiaceae (Huperzia and Lycopodium, in turn) as well as Selaginella increase their share among the spores. These changes taken together with the deposit type made it possible to distinguish the main trends in the palynofloral assemblages.

\section{PLANT COMMUNITIES - SEDIMENTARY SETTING AND PALAEOCLIMATE}

Pollen analysis indicates that the sediment studied was deposited in a water body surrounded by herbaceous vegetation as well as by mixed and coniferous forests. More elevated habitats in the area studied were forested with conifers, of which Picea as well as Pinus, Abies, Tsuga, and Sciadopitys were particularly important. Ericaceae and Lycopodiaceae were probably components of the groundcover of these coniferous forests, or they formed their own communities. Along riversides and streams favourable conditions existed for riparian forests dominated by Alnus, Ulmus, Salix, Betula, and accompanied by Pterocarya, Carya, Juglans, Acer, and others. In places with high ground-water level, Taxodium and lone Nyssa trees probably also grew. Drier higher terrains were presumably covered by mixed forests with Fagus, Quercus, Carpinus, Castanea and Betula, accompanied by Tilia, Aesculus, Corylus and conifers. The hemi-parasitic shrub Viscum lived on tree stems.

The occurrence of aquatic pollen (e.g., Nymphaeaceae) and abundant freshwater algae (mainly Pediastrum, Botryococcus, Sigmopollis and morphologically differentiated Zygnemataceae zygospores) points to sedimentation in a freshwater body. Most of the algae identified prefer mesotrophic to eutrophic conditions, and are characteristic of stagnant or slow-flowing, shallow water (Appendix 3). For example, modern Botryococcus mainly lives in freshwater bogs, temporary pools, ponds and lakes. The genus Sigmopollis is associated with eutrophic to mesotrophic open waters (Pals et al., 1980). Also, most of the filamentous algae of the Zygnemataceae family occur in shallow, stagnant, clean, oxygen-rich waters. They may, however, also occur near lake margins, in slow-flowing water and in moist soils or bogs (Kadłubowska, 1972; van Geel and Grenfell, 1996; Johnson, 2005; Naselli-Flores and Barone, 2009). In temperate climatic zones Zygnemataceae conjugate in shallow (often less than $0.5 \mathrm{~m}$ ), relatively warm water, forming dormant hypnozygotes that may be exposed to desiccation (e.g., in summer) without damage to the living contents (van Geel, 2001). On the other hand, the presence of sediment layers with abundant Pediastrum algae accompanied by Tetraedron suggests that, at least during some periods, the water was stagnant or only slow-flowing. Pediastrum algae are often found in the phytoplankton of lakes and ponds. Pediastrum boryanum generally occurs in eutrophic waters, whereas Pediastrum integrum is an alga found mainly in oligotrophic and dystrophic water biotopes (Komárek and Jankovská, 2001). The temporary pres- 
ence of both of these taxa suggests changes in the water biotope.

Among the floating and rooted macrophytes were Nuphar, Nymphaea, Potamogeton, Utricularia, and probably also Ludwigia and Lemna. The water body was surrounded by swamp-aquatic vegetation, composed of herbs, including Typha (e.g., T. latifolia), Sparganium, Alismataceae (Alisma and Sagittaria), sedges, grasses, Apiaceae, Caryophyllaceae, Ranunculaceae (e.g., Thalictrum), Polygonaceae (e.g., Polygonum), Lythraceae, Lamiaceae, Chenopodiaceae, Onagraceae and Asteraceae. On damp and shady soils, rocks and crags Selaginella and Theligonum probably grew (Rutishauser et al., 1998; Jiarui and Funston, 2011). The occurrence of pollen grains of such taxa as Artemisia and Ambrosia also points to the presence of light-demanding and open-country plant communities, though growing in drier places.

Pollen analysis of the Mizerna-Nowa profile revealed changes in the frequency of particular taxa (Figs. 6 and 7A). Changes in the palynoflora reveal, in turn, a decrease in mixed forests relatively rich in warm-temperate taxa, the development of more light-demanding and open-landscape plant communities and, finally, an increase in coniferous forests containing Picea, Pinus, Tsuga and Abies, which fare badly among warm-temperate taxa. The main change in the composition of the spore-pollen spectra is a decrease in both palaeotropical and warm-temperate taxa (Fig. 7B). Although the composition of the spore-pollen spectra is also connected with facies conditions, they point to gradual changes in vegetation and the palaeoclimate during sedimentation. Unfortunately, because of the deposit type, there is no possibility of relating the observed changes to the vegetational succession within climatic cycles (such as the millenial-scale or Milankovich cycles) described at other Pliocene localities (Kloosterboer-van Hoeve et al., 2006).

Over the profile as a whole, the predominance of plants belonging to genera that now grow under temperate climatic conditions, the low proportion of warm temperate plants and scarce presence of tropical taxa is evident (Fig. 7B). However, some of the plant taxa and Tetraploa fungi encountered have recently occurred in areas with a mild climate (Worobiec et al., 2009; Karpińska-Kołaczek et al., 2010). All these observations indicate that the climate during deposition of the studied deposits was temperate (distinctly cooler than during the Miocene, but still warmer than the present-day climate of Poland). This state is consistent with those inferred from other Pliocene localities (Salzmann et al., 2011).

The presence of the Microthyriales epiphyllous micro-fungi, especially in the lower part of the profile studied, suggests generally high total annual rainfall - probably over $1000 \mathrm{~mm}$ (Elsik, 1978 ) or high air humidity (G. Worobiec, pers. comm.). In the sub-mountainous area the annual rainfall was probably higher than in the lowlands.

\section{AGE OF THE PALYNOFLORA}

Comparison of the Mizerna-Nowa profile with results from previous palynological investigations of the Mizerna A profile studied by Oszast (Szafer, 1954; Szafer and Oszast, 1964; Oszast, 1973; unpublished data from the lower part of the profile) introduces a new interpretation of the age of the Mizerna fossil flora. In the previously examined material a high frequency of indeterminate pollen and spores was reported. Moreover, the algal micro-remains, which can yield significant data, e.g. concerning sedimentation, were not studied in the previous investigations.
These circumstances indicate that only the main palynofloral trends reported from both Mizerna profiles are similar.

Comparison of the Mizerna-Nowa palynoflora with the Neogene palynofloras of southern Poland revealed the former's similarity to some Pliocene assemblages. For example, there are many similarities to the assemblage from Krościenko on the Dunajec (Oszast, 1973), considered on the basis of fruit-and-seed flora to be Early Pliocene in age (Szafer, 1946-1947). In particular, the lowermost part of the Mizerna-Nowa profile is most similar to the Krościenko spore-pollen assemblage. At both localities the most widespread (by far) coniferous tree was Picea, which, together with an admixture of Abies, Pinus, Tsuga, and Sciadopitys, composed the coniferous-forest communities. The deciduous and mixed forests growing both in the immediate and more distant environment at Krościenko were composed mainly of Alnus, Pterocarya, Carya, Salix, Fagus, Quercus, Carpinus, Tilia, Betula, Corylus, Ulmus and Acer. The frequency of particular taxa in both profiles is similar. The main difference is the abundance of Pterocarya pollen in the Krościenko profile. In both these assemblages, pollen of the Pinus haploxylon type/Cathaya and Taxodioideae tend not to exceed $10 \%$, whereas only single grains of Nyssa pollen were recorded.

The palynoflora studied is also very similar to the assemblage from Domański Wierch near Czarny Dunajec, Nowy Targ-Orawa Basin (West Carpathians), considered to be Late Pliocene in age (Oszast, 1973; Oszast and Stuchlik, 1977). In the Domański Wierch profile, a marked dominance of such conifers as Pinus and Picea, accompanied by Abies and Tsuga, occurs. Pollen of the Pinus haploxylon type/Cathaya and of theTaxodioideae is regularly encountered, tending not to exceed $10 \%$ in frequency. Of the deciduous trees and shrubs, Alnus is the most frequent, while Betula, Quercus, Fagus, Pterocarya, Carya, Ulmus, Tilia, Fraxinus and Carpinus occur commonly. Pollen analysis of this site revealed the presence of several plant communities adapted to different types of topography and habitat. The communities in the wet habitat were composed of Alnus, with an admixture of other riparian taxa. Drier habitats were occupied by deciduous forests of a different type, while higher up there were coniferous forests with a predominance of Picea.

The Mizerna-Nowa spore-pollen assemblage is also similar to the Pliocene palynoflora from Kłodzko, Kłodzko Basin, central Sudetes (Jahn et al., 1984). The main difference is the abundance of Aesculus pollen in the Kłodzko II profile. In both Kłodzko profiles the conifers that were particularly abundant were Pinus sylvestris and Picea, as well as Tsuga, Sciadopitys and Abies; whereas among deciduous trees it was the following that predominated: Alnus, Fagus, Quercus, Ulmus, Carya and Carpinus. Aesculus, Betula, Tilia, and Pterocarya pollen also occurred regularly. Pollen of the Pinus haploxylon type/Cathaya and Taxodioideae do not exceed $6 \%$, whereas only single grains of Nyssa and Sequoia pollen were recorded. Of the herbs, Poaceae, Cyperaceae, Apiaceae, Asteraceae, and Nymphaeaceae were most frequent. Pollen analysis of the Kłodzko profiles indicated a standing water body environment, probably (an) ox-bow lake(s), with abundant aquatic plants. This water body was surrounded by alder-rich marshy meadows, with an admixture of trees, shrubs, and herbs typical of wet habitats. Somewhat further away the area was covered by mixed forests with shrubs and climbers. Some of the conifer pollen, particularly the Picea pollen, is likely to have been derived from the coniferous forests which occurred at higher altitudes around the Kłodzko Basin.

The palynoflora studied also shows some similarities to Pliocene assemblages from Tułowice, southeastern Silesian 
Lowland, SW Poland (Badura et al., 2006). Although the frequency of Picea, Tsuga, Sciadopitys, Fagus and herb pollen as well as spores is noticeably higher in the Mizerna-Nowa material, there are distinct similarities as regards vegetational changes. The lower part of the Tułowice I pollen profile is dominated by coniferous trees (Pinus, Picea, Abies), and the middle part shows a marked contribution from herbaceous (Poaceae, Artemisia, Chenopodiaceae) and light-demanding plants. The upper part of the profile suggests the disappearance of light-demanding and open-country plant communities, which were replaced again by (mainly coniferous) forests containing Pinus, Picea and Abies. Another characteristic feature of the Tułowice and Mizerna-Nowa palynofloras is the presence of relatively numerous Theligonum pollen grains. The various plant assemblages probably reflected distinct differences between the sub-mountainous plant communities, which mainly consisted of conifer forest, and lowland plant communities consisting of deciduous forest with a small admixture of warm-temperate taxa, existing during the Pliocene (Piwocki and Ziembińska-Tworzydło, 1997).

On the other hand, the pollen diagram from Mizerna-Nowa distinctly differs from the pollen diagram from Różce, central Poland (Stuchlik, 1987, 1994), in which the Pliocene/Pleistocene boundary was recognized. There, at this boundary, pollen from warm-temperate taxa disappears and Pinus and Picea pollen decreases, whereas Betula (including $B$. nana) and herb pollen increases. In the Mizerna-Nowa profile such changes have not been observed (Fig. 6). In the material studied, changes are gradual, for example Fagus pollen is present throughout the profile with only a small drop in frequency in its middle part. Similarly, the palynoflora studied more closely resembles the pollen assemblage from the lower (Pliocene) part of the Ponurzyca profile, central Poland (Stuchlik, 1975), in which the Pliocene/Pleistocene boundary is probably also pres- ent. Moreover, the palynoflora studied revealed only negligible similarities to other Pleistocene assemblages, e.g. the lowermost part of the Szaflary profile, West Carpathians (Birkenmajer and Stuchlik, 1975), in which Quaternary taxa distinctly prevail.

The palynostratigraphy of the inland Pliocene deposits in Poland has not been worked out in detail yet because it is based on scarce spore-pollen profiles (Grabowska, 1998). According to Ziembińska-Tworzydło (1998; Piwocki and ZiembińskaTworzydło, 1997), two climatic phases, XIII and XIV, can be identified in the Pliocene. These phases are connected with the Sequoiapollenites and Faguspollenites spore-pollen zones. The Mizerna-Nowa profile reveals many similarities to both these zones, mainly in the composition of spore-pollen spectra and in the main vegetational succession. Therefore, a Pliocene (sensu lato) age of the whole Mizerna-Nowa palynoflora can be suggested. Compared with palynofloras from other localities, the assemblage studied is probably somewhat younger than the Early Pliocene palynoflora from Krościenko on the Dunajec and older than the Pliocene/Pleistocene Różce palynoflora. The Mizerna-Nowa profile reveals a pre-Pleistocene change in vegetation due to increasing aridity and climate cooling.

Acknowledgements. The palynological studies have been supported by the W. Szafer Institute of Botany, Polish Academy of Sciences through the statutory fund. The author (EW) would like to thank Dr. hab. G. Worobiec (W. Szafer Institute of Botany, PAS, Kraków) for his help in taking photographs and M.Sc. A. Sojka (W. Szafer Institute of Botany, PAS, Kraków) for her help in preparing the figures, as well as Dr. M. ZiembińskaTworzydło (Warsaw University), Prof. E. ZastawniakBirkenmajer, Prof. L. Stuchlik (W. Szafer Institute of Botany, PAS, Kraków), Dr. N. Doláková (Masaryk University, Brno) and anonymous reviewers for their comments on the manuscript.

\section{REFERENCES}

Badura J., Przybylski B., Salamon T., Winter H. (2006) Sedimentological and palaeobotanical records of climatic changes within Pliocene fluvial sediments in the southeastern Silesian Lowland (in Polish with English summary). Biuletyn Państwowego Instytutu Geologicznego, 421: 1-14.

Birkenmajer K. (1954) Geological investigations of the Podhale Neogene, Central Carpathians (in Polish with English summary). Biuletyn Instytutu Geologicznego, 86: 59-79.

Birkenmajer K. (1958) Przewodnik geologiczny po pienińskim pasie skałkowym, I-IV. Wydawnictwa Geologiczne, Warszawa.

Birkenmajer K. (1961) Mizerna near Czorsztyn: Pliocene and Older Pleistocene deposits. INQUA VIth Congress Guide-Book of excursions. From the Baltic to the Tatras, part 3, South Poland: 151-155. Wydawnictwo Naukowe, Łódź.

Birkenmajer K. (1963) Mapa geologiczna pienińskiego pasa skałkowego, 1:10 000, ark. Czorsztyn. Instytut Geolgiczny, Warszawa.

Birkenmajer K. (1976) Pleistocene tectonic deformations at Szaflary, West Carpathians (in Polish with English summary). Annales Societatis Geologorum Poloniae, 46 (3): 309-323.

Birkenmajer K. (1979) Przewodnik geologiczny po pienińskim pasie skałkowym. Wydawnictwa Geologiczne, Warszawa.
Birkenmajer K. (2009) Quaternary glacigenic deposits between the Biała Woda and the Filipka valleys, Polish Tatra Mts, in the regional context. Studia Geologica Polonica, 132: 91-115.

Birkenmajer K. (2010) Lost and/or saved monuments of inanimate nature in the area of artificial water reservoirs Czorsztyn-Sromowce, Pieniny Mts, West Carpathians (in Polish with English summary). Monografie Pienińskie, 2: 43-51.

Birkenmajer K., Oszczypko N. (1988) New lithostratigraphic standard for the Palaeogene of the Magura Flysch Basin (southern part), Carpathians. Bulletin of the Polish Academy of Sciences, Earth Sciences, 36 (3-4): 253-259.

Birkenmajer K., Oszczypko N. (1989) Cretaceous and Palaeogene lithostratigraphic units of the Magura Nappe, Krynica Subunit, Carpathians. Annales Societatis Geologorum Poloniae, 59: 117-153.

Birkenmajer K., Stuchlik L. (1975) Early Pleistocene pollen-bearing sediments at Szaflary, West Carpathians, Poland. Acta Palaeobotanica, 16: 113-146.

Birkenmajer K., Hrynowiecka-Czmielewska A., Stuchlik L. (2010) Pollen-bearing Middle Pleistocene deposits at Huba southern Poland (West Carpathians). Acta Palaeobotanica, 50 (2): 89-99. 
Elsik W.C. (1978) Classification and geologic history of the microthyriaceous fungi. Proceedings IV International Palynological Conference Lucknow (1976-77), 1: 331-342.

Grabowska I. (1998) The Neogene palynostratigraphy in the Polish Lowlands. Prace Państwowego Instytutu Geologicznego, 160 $16-18$.

Head M.J. (1992) Zygospores of Zygnemataceae (Division Chlorophyta) and other freshwater algal spores from the uppermost Pliocene St. Erth Beds of Cornwall, southwestern England. Micropaleontology, 38: 237-260.

Jahn A., Łańcucka-Środoniowa M., Sadowska A. (1984) The site of Pliocene deposits in the Kłodzko Basin, Central Sudetes (in Polish with English summary). Geologica Sudetica, 18 (2): 7-43.

Jiarui C., Funston A.M. (2011) 91. Theligonum Linnaeus, Sp. PI. 2 : 993. 1753. Flora of China, 19: 346-347.

Johnson L.R. (2005) Family Zygnemataceae. In: The Freshwater Algal Flora of the British Isles. An identification guide to freshwater and terrestrial algae (eds. D.M. John, B.A. Whitton and A.J. Brook): 480-510. Cambridge University Press.

Kadłubowska J. (1972) Chlorophyta V. Conjugales: Zygnemaceae. Zrostnicowate. In: Flora słodkowodna Polski (eds. K. Starmach and J. Siemińska). Vol. 12A. PWN, Polska Akademia Nauk. Kraków.

Karpińska-Kołaczek M., Kołaczek P., Heise W., Worobiec G. (2010) Tetraploa aristata Berkeley \& Broome (Fungi, Pleosporales), a new taxon to Poland. Acta Societatis Botanicorum Poloniae, 79 (3): 239-244.

Kloosterboer-van Hoeve M.L., Steenbrink J., Visscher H., Brinkhuis H. (2006) Millennial-scale climatic cycles in the Early Pliocene pollen record of Ptolemais, northern Greece. Palaeogeography, Palaeoclimatology, Palaeoecology, 229 (4): 321-334.

Komárek J., Jankovská V. (2001) Review of the green algal genus Pediastrum; implication for pollen-analytical research. Bibliotheca Phycologica, 108: 1-127.

Moore P.D., Webb J.A., Collinson M.E. (1991) Pollen analysis. Blackwell Scientific Publications, Oxford.

Nalepka D., Walanus A. (2003) Data processing in pollen analysis. Acta Palaeobotanica, 43 (1): 125-134.

Naselli-Flores L., Barone R. (2009) Green algae. In: Encyclopedia of Inland Waters (ed. G.E. Likens), 1: 166-173. Elsevier, Oxford, pp.

Niedzielski H. (1971) Tektoniczne pochodzenie wschodniej części Kotliny Nowotarskiej. Rocznik Polskiego Towarzystwa Geologicznego, 61: 397-408.

Oszast J. (1973) The Pliocene profile of Domański Wierch near Czarny Dunajec in the light of palynological investigations (Western Carpathians, Poland). Acta Palaeobotanica, 14 (1): 3-42.

Oszast J., Stuchlik L. (1977) The Neogene vegetation of the Podhale (West Carpathians, Poland) (in Polish with English summary). Acta Palaeobotanica, 18 (1): 45-86.

Pals J.P., van Geel B., Delfos A. (1980) Paleoecological studies in the Klokkeweel bog near Hoogkarspel (prov. of Noord-Holland). Review of Palaeobotany and Palynology, 30: 371-418.

Piwocki M., Ziembińska-Tworzydło M. (1997) Neogene of the Polish Lowlands - lithostratigraphy and pollen-spore zones. Geological Quarterly, 41: 21-40.

Rutishauser R., Ronse Decraene L.P., Smets E., Mendoza-Heuer I. (1998) Theligonum cynocrambe: developmental morphology of a peculiar rubiaceous herb. Plant Systematics and Evolution, 210: 1-24.

Salzmann U., Williams M., Haywood A.M., Johnson A.L.A., Kender S., Zalasiewicz J. (2011) Climate and environment of a Pliocene warm world. Palaeogeography, Palaeoclimatology, Palaeoecology, 309: 73-82.
Stuchlik L. (1975) Palynological characteristics of the Preglacial sediments of Ponurzyca, Otwock area (in Polish with English summary). Kwartalnik Geologiczny, 19 (3): 667-678.

Stuchlik L. (1987) Review of palaeobotanical studies on Pliocene and Lower Pleistocene deposits in central and southern Poland (in Polish with English summary). In: Problemy młodszego neogenu i eoplejstocenu w Polsce (eds. A. Jahn and S. Dyjor): 53-63. Ossolineum, Wrocław.

Stuchlik L. (1994) Some Late Pliocene and Early Pleistocene pollen profiles from Poland. In: Cenozoic Plants and Climates of the Arctic (eds. M.C. Boulter and H.C. Fisher). NATO-ASI Series I, 27: 371-382.

Stuchlik L., Ziembińska-Tworzydło M., Kohlman-Adamska A., Grabowska I., Wa yńska H., Słodkowska B., Sadowska A. (2001) Atlas of pollen and spores of the Polish Neogene. Volume 1 - Spores. W. Szafer Institute of Botany, Polish Academy of Sciences, Kraków.

Stuchlik L., Ziembińska-Tworzydło M., Kohlman-Adamska A., Grabowska I., Wa yńska H., Sadowska A. (2002) Atlas of pollen and spores of the Polish Neogene. Volume 2 - Gymnosperms. W. Szafer Institute of Botany, Polish Academy of Sciences, Kraków.

Stuchlik L., Ziembińska-Tworzydło M., Kohlman-Adamska A. Grabowska I., Słodkowska B., Wa yńska H., Sadowska A. (2009) Atlas of pollen and spores of the Polish Neogene. Volume 3 - Angiosperms (1). W. Szafer Institute of Botany, Polish Academy of Sciences, Kraków.

Szafer W. (1946-1947) The Pliocene flora of Krościenko in Poland). | - General part -1946, || - Descriptive part - 1947 (in Polish with English summary). Polska Akademia Umiejętności, Rozprawy Wydziału III, Kraków.

Szafer W. (1949) Przedzjazdowa wycieczka na Podhale. XXII Zjazd Naukowy Polskiego Towarzystwa Geologicznego.

Szafer W. (1952) The young Tertiary of the Podhale and its relation with the Pleistocene (in Polish with English summary). Biuletyn Instytutu Geologicznego, 56: 555-556.

Szafer W. (1954) Pliocene flora from the vicinity of Czorsztyn and its relationship to the Pleistocene (in Polish with English summary). Prace Instytutu Geologicznego, 11: 1-238.

Szafer W., Oszast J. (1964) The decline of Tertiary plants before the Maximal glaciation of the West Carpathians. In: Report of the 6th International Congress on Quaternary (ed. J. Dylik): 479-482, II (Palaeobotanic Section). Warszawa-Łódź, 1961.

Van Geel B. (1978) A palaeoecological study of Holocene peat bog sections in Germany and The Netherlands. Review of Palaeobotany and Palynology, 25: 1-120.

Van Geel B. (2001) Non-pollen palynomorphs. In: Tracking Environmental Change Using Lake Sediments, volume 3 - Terrestrial, algal, and siliceous indicators (eds. J.P. Smol, H.J.B. Birks and W.M. Last): 99-119. Kluwer Academic Publishers, Dordrecht.

Van Geel B., Grenfell H.R. (1996) Chapter 7A. Spores of Zygnemataceae. American Association of Stratigraphic Palynologists Foundation, 1: 173-179.

Van Geel B., Bohncke S.J.P., Dee H. (1981) A palaeoecological study of an upper Late Glacial and Holocene sequence from "De Borchert", The Netherlands. Review of Palaeobotany and Palynology, 31: 367-448.

Van Geel B., Hallewas D.P., Pals J.P. (1983) A Late Holocene deposits under the Westfriese Zeedijk near Enkhuizen (Prov. Noord-Holland, The Netherlands): palaeoecological and archaeological aspects. Review of Palaeobotany and Palynology, 38: 269-335.

Worobiec E. (2010) Late Miocene freshwater phytoplankton from Józefina (Poland). Micropaleontology, 56 (6): 517-537.

Worobiec E. (2011) Middle Miocene aquatic and wetland vegetation of the paleosinkhole at Tarnów Opolski, SW Poland. Journal of Paleolimnology, 45 (3): 311-322. 
Worobiec E., Worobiec G., GedI P. (2009) Occurrence of fossil bamboo pollen and a fungal conidium of Tetraploa cf. aristata in Upper Miocene deposits of Józefina (Poland). Review of Palaeobotany and Palynology, 157 (3-4): 211-217.

Zastawniak-Birkenmajer E., Birkenmajer K. (2012) Problem of the Pliocene/Pleistocene boundary in fresh-water deposits at Mizerna, West Carpathians (in Polish with English summary). Przegląd Geologiczny, 60 (5): 276-283.
Ziembińska-Tworzydło M. (1998) Climatic phases and spore-pollen zones. Prace Państwowego Instytutu Geologicznego, 160: 12-16.

Ziembińska-Tworzydło M., Grabowska I., Kohlman-Adamska A., Sadowska A., Słodkowska B., Stuchlik L., Ważyńska H. (1994) Checklist of selected genera and species of spores and pollen grains ordered in morphological system. Acta Palaeobotanica, Supplemented, 1: 31-56. 